\title{
ANALISIS ALOKASI BIAYA BERSAMA UNTUK MENENTUKAN HARGA POKOK PRODUKSI PADA UD. VANELA
}

\author{
Farahdiba \\ Grace B. Mogi \\ Stanly Kho Walandow \\ Fakultas Ekonomi dan Bisnis Jurusan Akuntansi \\ Universitas Sam Ratulangi Manado \\ email : farahdibararaa@gmail.com
}

\begin{abstract}
ABSTRAK
Biaya bersama adalah biaya yang diolah secara bersama seperti biaya tenaga kerja langsung, dan biaya overhead pabrik untuk menghasilkan beberapa produk. Dimana perhitungan alokasi biaya bersama bertujuan untuk menghitung harga pokok dan menentukan persediaan untuk tujuan pelaporan eksternal, Adapun tujuan penelitian ini adalah untuk melakukan analisis alokasi biaya bersama dalam penentuan harga pokok produksi yang tepat pada UD. Vanela. Metode yang digunakan dalam perhitungan biaya bersama ini adalah metode nilai jual relative. Dari hasil penelitian disimpulkan bahwa alokasi biaya bersama berdasarkan tabel perbandingan bahwa perbedaan pengalokasian biaya berbeda karena UD. Vanela memperhitungkan harga pokok produk untuk keseluruhan produk sehingga biaya-biaya yang seharusnya dialokasikan tiap produk tidak dialokasikan dengan sesuai, sedangkan untuk perhitungan alokasi biaya bersama sesuai dengan pengalokasian biaya yang seharusnya. Dengan menggunakan metode nilai jual relative pengalokasian biaya menjadi lebih jelas sesuai dengan yang seharusnya dan berdasarkan sumber buku yang ada.
\end{abstract}

Kata kunci : Biaya Bersama, Harga Pokok Produksi.

\begin{abstract}
Joint cost is the cost that processing together at the same time as the cost of direct labor and factory overhead costs to produce multiple product. To determining of joint cost need to calculation the cost of production, that purpose was to calculate and determining supply of external report, the aim of this research is to doing analysis the allocation of joint cost in determining cost of production on Vanela. The method of this research is relative sales value method. The final conclution is that the joint cost allocation is based on a comparison table that difference in cost allocation is different because Vanela take into account the overall cost of the product to the product so the cost should be allocated costs of each product are not allocated according to the calculation of cost allocation, and for the calculation of joint cost is according with the allocation of costs that should be. If using the relative sales value method the cost of allocation becomes more obvious as it should be and based on the book.
\end{abstract}

Key word : Joint Cost, Cost of Production 


\section{PENDAHULUAN}

\section{Latar Belakang Masalah}

Begitu banyak perusahaan yang telah meniti karir dibidangnya dan telah menuai kesuksesannya maupun yang masih baru akan mulainya, sehingga menimbulkan begitu banyak persaingan pula, oleh karenanya setiap perusahaan harus mempunyai strategi tersendiri untuk terus mengembangkannya. Dimana dalam hal ini pihak manajemen sangat berperan penting dalam menentukan keputusan dalam proses penentuan biaya-biaya dan pengalokasian biaya, oleh karenanya pihak manajemen harus berhati-hati dalam pengalokasian biaya.

Biaya bersama sulit diperhitungkan kepada masing-masing produk sehingga diperlukan alokasi biaya. Dengan pengaalokasian biaya maka perusahaan dapat menghitung harga pokok produksi dan menentukan nilai persediaan untuk tujuan pelaporan keuangan internal dan eksternal. UD. Vanela merupakan home industri yang mengelola Kue Pia Kering menjadi 3 rasa yaitu Pia cokelat, Pia keju, dan Pia kacang hijau. Yang tentunya membutuhkan pengalokasian biaya dari segi bahan baku, biaya tenaga kerja, dan biaya overhead pabrik.

Dalam hal ini UD. Vanela tidak menggunakan metode khusus untuk melakukan penjualannya dalam menentukan harga pokok produksi pada pia cokelat, pia keju dan pia kacang hijau. UD. Vanela hanya memperhitungkan pendapatan dan pengeluaran berdasarkan penggunaan bahan baku, biaya tenaga kerja dan biaya overhead pabrik untuk per bulan. Oleh karena itu dibutuhkan pengalokasian biaya terhadap UD. Vanela agar biaya-biaya teralokasikan dengan benar.

\section{Tujuan Penelitian}

Adapun tujuan yang ingin dicapai dalam penelitian ini adalah, untuk melakukan analisis alokasi biaya bersama dalam penentuan harga pokok produksi pada UD. Vanela.

\section{Manfaat Penelitian}

1. Perusahaan, sebagai bahan evaluasi dalam pengalokasian biaya bersama dan sebagai sumbangan pemikiran dalam menentukan harga pokok produk yang tepat .

2. Bagi Pihak Manajemen, hasil penelitian ini diharapkan dapat menjadi masukan dan refrensi dalam melakukan evaluasi untuk meningkatkan kinerja perusahaan.

3. Penulis, Untuk lebih menerapkan teori dalam praktek mengenai alokasi biaya bersama dalam menentukan harga pokok produksi.

\section{TINJAUAN PUSTAKA}

\section{Pengertian Biaya Bersama}

Definisi biaya bersama menurut Mulyadi (2012 ; 333) Biaya bersama dapat diartikan sebagai biaya overhead bersama (joint overhead cost) yang harus dialokasikan ke berbagai departemen, baik dalam perusahaan yang kegiatan produksinya berdasarkan pesanan maupun yang kegiatan produksinya dilakukan secara masa.

Dan menurut Mulyadi (2012 : 333) biaya bersama dapat diartikan sebagai overhead bersama (joint overhead cost) yang harus dialokasikan ke berbagai departemen, baik dalam perusahaan yang kegiatan produksinya berdasarkan pesanan maupun yang kegiatan produksinya dilakukan secara masa.

\section{Tujuan Alokasi Biaya Bersama}

Secara umum alokasi biaya tersebut ditujukan untuk berbagai alasan sebagai berikut (Bastian Bustami dan Nurlela 2009 : 149):

1. Untuk menghitug harga pokok dan menentukan nilai persediaan untuk tujuan pelaporan internal

2. Menghitung harga pokok dan menentukan persediaan untuk tujuan pelaporan eksternal

3. Menilai persediaan untuk tujuan asuransi

4. Menentukan nilai persediaan jika terjadi kerusakan terhadap nilai barang yang rusak

5. Biaya bahan yang hancur 
6. Menentukan biaya departemen atau devisi untuk tujuan pelaporan kinerja eksekutif

7. Pengaturan tarif karena adanya sebagian produk atau jasa yang diproduksi dikenakan peraturan harga.

Selain dari tujuan-tujuan diatas, Mursyidi (2008 :165) juga memaparkan bahwa analisis biaya bersama dapat dijadikan informasi untuk perencanaan laba sekaligus penentuan harga jual yang relatif bersaing untuk setiap jenis produk bersama.

\section{Karakteristik Biaya Bersama}

Karakteristik produk bersama menurut Abdul Halim (2012;232) adalah sebagai berikut:

1. Produk bersama mempunyai hubungan fisik yang sangat erat satu sama lain dalam proses produksinya. Bila ada tambahan kuantitas untuk menambah unit produk yang lain maka kuantitas produk yang lain akan bertambah secara proporsional.

2. Tidak ada satu produk pun dari produk bersama yang secara signifikan nilainya lebih tinggi dari produk lain.

3. Dalam proses produk bersama dikenal istilah "titik pisah" yakni saat terpisahnya (split-off) masing-masing jenis produk yang dihasilkan dari bahan baku, tenaga kerja dan overhead yang telah dinikmati produk secara bersama-sama.

4. Setelah terpisah (split- off) produk berdiri sendiri-sendiri yang mungkin langsung dijual atau mungkin pula harus diproses lebih lanjut untuk mendapatkan produk yang lebih menguntungkan.

\section{Pengertian Split Off}

Perusahaan bekerja dan berproduksi secara bersama-sama atau berbarengan dan sampai suatu titik tertentu produk yang dihasilkan dipisahkan dan menjadi barang-barang lain yang berbeda. Titik inilah dinamakan sebagai titik pisah batas atau split off point.

\section{Metode Alokasi Biaya Bersama}

Metode alokasi biaya bersama menurut Abdul Halim $(2012 ; 234)$ :

1. Metode Nilai Harga Jual

Menurut metode ini biaya bersama dialokasikan menurut nilai harga jual dari masing-masing atau jenis produk. Menurut metode ini pengalokasian biaya bersama dapat menimbulkan situasi :

a. Bila harga jual sudah diketahui saat split off maka biaya bersama dialokasikan ke masing-masing jenis produk dengan cara membagi total nilai jual seluruh produk yang diproduksi yang akan menghasilkan rasio dari masing-masing jenis produk. Rasio ini kemudian dilakalikan dengan total biaya bersama.

b. Harga jual tidak diketahui pada saat split off

Harga jual produk bersama pada saat split off sangat mungkin tidak diketahui terutama sekali bila produk tersebut masih memerlukan proses produksi lebih lanjut.

2. Metode Unit Kuantitas

Menurut metode ini dasar alokasi dari biaya bersama adalah jumlah kuantitas yang diproduksi untuk masingmasing produk. Satuan kuantitas yang dimaksud dalah seperti unit, ton, kilogram, buah, biji, meter dan lain sebagainnya.

3. Metode Harga Pokok Per Unit

Menurut metode ini alokasi biaya bersama didasarkan pada harga pokok per unit dari keseluruhan produk yang dihasilkan. Untuk menghitung harga pokok per unit tersbut dapat dilakukan dengan :

a. Metode rata-rata sederhana

Dalam metode rata-rata sederhana untuk mendapatkan harga pokok per unit adalah dengan membagi total biaya bersama dengan total kuantitas yang diproduksi.

b. Metode rata-rata tertimbang

Metode ini mendapatkan dasar alokasi diperlukan suatu penimbang atau bobot. 


\section{Harga Pokok Produksi}

Menurut Hansen and Mowen ( 2006), harga pokok poduksi merupakan jumlah biaya barang yang diselesaikan selama periode berjalan. Biaya yang hanya dibebankan ke barang yang diselesaikan adalah biaya produksi dari bahan baku langsung, tenaga kerja langsung dan biaya overhead. Harga pokok produksi dalah biaya yang dibeli untuk proses sampai selesai, baik sebelum maupun selama periode akuntansi berjalan (Hongren et al, 2006).

\section{Unsur-Unsur Harga Pokok Produksi}

Unsur-unsur biaya produksi atau jasa menurut Hansen dan Mowen (2003:42), dapat diklasifikasi dalam tiga jenis yaitu biaya bahan baku, biaya tenaga kerja langsung, dan biaya overhead.

1. Biaya Bahan Baku

Bahan baku merupakan dasar yang akan digunakan untuk membentuk bagian yang menyeluruh menjadi produk jadi. Bahan baku yang digunakan untuk memproduksi dapat diperoleh melalui pembelian lokal, impor atau dari pengelolaan sendiri.

2. Biaya Tenaga Kerja Langsung

Tenaga kerja merupakan kegiatan fisik yang dilakukan oleh karyawan untuk mengolah suatu produk. Biaya tenaga kerja meliputi biaya-biaya yang berkaitan dengan penghargaan dalam bentuk upah yang diberikan kepada semua tenaga kerja yang secara langsung ikut serta dalam pengerjaan produk.

3. Biaya Overhaed Pabrik

Pada umumnya dalam suatu perusahaan biaya bahan baku dan biaya tenaga kerja langsung merupakan biaya produksi langsung. Semua biaya selain biaya bahan baku dan biaya tenaga kerja langsung yang berhubungan dengan produksi adalah biaya produksi tidak langsung.

\section{Penelitian Terdahulu}

penelitian dari Sunarmi (2012) yang berjudul "Analisis Alokasi Biaya Bersama Untuk Produk Bersama Sate Kambing dan Tongseng pada UD. Pak Bardan". Novi Rusdiani (2012) yang berjudul "Pengalokasian Biaya Bersama Pada Produk Utama dan Produk Sampingan Pada Pabrik Gula Gempolkrep Mijokerto".

\section{METODE PENELITIAN}

\section{Jenis Penelitian}

Jenis penelitian yang digunakan adalah penelitian yang menggunakan metode kualitatif. Menurut Sugiono (2012:7) Pendekatan kualitatif adalah suatu proses penelitian dan pemahaman yang berdasarkan pada metodologi yang menyelidiki suatu fenomena sosial dan masalah manusia.

\section{Tempat dan Waktu Penelitian}

Penelitian dilaksanakan pada UD. Vanela berlokasi di Malalayang, Jl. Sea Lorong Emanuel no 7A Manado. Penelitian ini dilaksanakan pada bulan November 2013-Januari 2014.

\section{Metode Pengumpulan Data Jenis Data}

1. Data Kualitatif, data yang tidak dapat diukur dalam skala numerik atau dalam angka. Data kualitatif diperoleh melalui berbagai macam teknik pengumpulan data misalnya wawancara, analisis dokumen atau observasi. Data kualitatif yang nantinya akan diambil seperti wawancara mengenai proses produksi pada UD. Vanela.

2. Data Kuantitatif, data yang diukur dalam suatu skala numerik atau dalam angka. Data kuantitatif terdiri dari biaya produksi yaitu bahan baku, tenaga kerja langsung dan biaya overhead pabrik dan jumlah produksi.

\section{Sumber Data}

1. Data Primer

Merupakan data yang diperoleh langsung dari perusahaan atau data yang terjadi di lapangan seperti data mengenai sejarah singkat perusahaan, struktur organisasi, tentang pembagian tugas. Dan yang diperoleh dari 
teknik wawancara, kemudian akan diolah penulis, seperti : wawancara dengan staf bagian yang berkaitan dengan data-data produksi UD. Vanela mengenai proses produksi, biaya produksi dan jumlah produksi.

\section{Data Sekunder}

Merupakan data yang diperoleh dari penelitian orang lain atau sumber yang telah dipublikasikan sehingga data tersebut telah tersedia seperti data yang dapat di peroleh melalui perpuskatakaan umum. Dalam penelitian ini yang menjadi data sekunder adalah penelitian terdahulu yang mempunyai judul yang hampir serupa dengan yang sedang diteliti saat ini sehingga menjadi sumber acuan untuk membuat penelitian ini, dan selain itu buku-buku yang terkait pun juga menjadi acuan penelitian ini.

\section{Teknik Pengumpulan Data}

1. Wawancara yaitu pertanyaan-pertanyaan yang diajukan oleh peneliti secara lebih bebas dan leluasa tanpa terikat oleh suatu susunan pertanyaan yang sudah dipersiapkan sebelumnya. Dalam penelitian ini proses wawancara yang diajukan kepada owner adalah wawancara mengenai hal-hal yang terkait dengan judul peneliti seperti: sejarah singkat perusahaan, data penggunaan bahan baku, biaya tenaga kerja, dan biaya overhead yang kemudian akan diolah kedalam pengalokasian biaya bersama.

2. Metode Observasi

Observasi merupakan pengamatan langsung di lapangan yang dilakukan oleh seorang peneliti. Dalam penelitian ini, yang diobservasi adalah perusahaan UD. Vanela yang menjadi tempat penelitian peneliti untuk memperoleh informasi-informasi yang dibutuhkan.

\section{Metode Analisis Data}

Dalam penelitian ini metode yang digunakan adalah metode deskriptif, dalam hal ini dilakukan dengan mengumpulkan biaya-biaya yang terkait, kemudian mengelompokannya kedalam biaya-biaya overhead pabrik, biaya tenaga kerja, dan biaya bahan baku untuk menentukan harga pokok produksi sesuai dengan teori yang ada.

\section{HASIL PENENITIAN DAN PEMBAHASAN}

\section{Hasil Penelitian}

\section{Proses Produksi UD. Vanela}

Proses produksi pia kering ini adalah sebagai berikut :

1. Tahap pertama : Semua bahan baku dicampur kemudian dibagi dalam 3 adonan untuk rasa cokelat, rasa keju, dan rasa kacang hijau.

2. Tahap kedua : Setelah dibagi dalam tiga bagian, kemudian dibentuk menjadi bulatan-bulatan kecil dan di isi beberapa rasa, rasa cokelat, keju, dan kacang hijau.

3. Tahap ketiga : Setelah dibentuk dan diberi isi kemudian kue pia pun siap untuk dipanggang dalam suhu yang telah ditentukan.

4. Tahap keempat : Pada tahap ini adalah menjadi tahap akhir, setelah diangkat dari oven, kue pia didiamkan untuk beberapa menit di tempat yang telah disediakan, kemudian di kemas dalam kemasan plastik, yang diamana tiap kemasan berisi 10 buah kue pia kering. Setelah dikemas kue pia pun siap untuk dipasarkan.

\section{Perhitungan Harga Pokok Produksi Menurut UD. Vanela}

Gambar 1 Harga Pokok Produk UD. Vanela

\begin{tabular}{|c|c|}
\hline Harga pokok produk: & \\
\hline Biaya bahan baku & $\mathrm{Rp} \quad 5.322 .000$ \\
\hline Biaya tenaga kerja langsung & Rp $\quad 6.360 .000$ \\
\hline Biaya overhead pabrik & $\underline{\mathrm{Rp}} \quad 1.794 .944$ \\
\hline Harga pokok produk & $\mathrm{Rp} 13.476 .944$ \\
\hline
\end{tabular}


Sumber: UD. Vanela, November 2013

Pada gambar 4.1 dijelaskan bahwa total harga pokok produksi pada UD. Vanela selama sebulan adalah Rp 13.476.944,-

\section{Pembahasan}

Biaya Bersama Pia Cokelat, Keju, dan Kacang Hijau

Tabel 1: Biaya Bersama UD. Vanela

\begin{tabular}{|l|l|}
\hline \multicolumn{1}{|c|}{ Jenis Biaya } & \multicolumn{2}{c|}{ Jumlah (Rp) } \\
\hline 1. Biaya Bahan Baku & 5.322 .000 \\
\hline 2. Biaya Tenaga Kerja & 6.360 .000 \\
\hline 3. Biaya Overhead Pabrik & 1.794 .944 \\
\hline Total Biaya & 13.476 .944 \\
\hline
\end{tabular}

Sumber: UD. Vanela November, 2013

\section{Data Penjualan PIA}

Tabel 2 : Data Penjualan Pia UD. Vanela. November, 2013

\begin{tabular}{|l|c|c|c|c|c|}
\hline Jenis Pia & $\begin{array}{c}\text { Produksi } \\
\text { per hari } \\
\text { (pak) }\end{array}$ & $\begin{array}{c}\text { Hari dalam } \\
\text { sebulan }\end{array}$ & $\begin{array}{c}\text { Produksi } \\
\text { per bulan } \\
\text { (pak) }\end{array}$ & $\begin{array}{c}\text { Harga jual } \\
\text { per (pak) }\end{array}$ & $\begin{array}{c}\text { Jumlah } \\
\text { penjualan } \\
\text { per bulan } \\
\text { (Rp) }\end{array}$ \\
\hline Pia Cokelat & 50 & 24 & 1.200 & 13.000 & 15.600 .000 \\
\hline Pia Keju & 50 & 24 & 1.200 & 12.000 & 14.400 .000 \\
\hline $\begin{array}{l}\text { Pia Kacang } \\
\text { Hijau }\end{array}$ & 50 & 24 & 1.200 & 10.500 & 12.600 .000 \\
\hline Total & 150 & & & & 42.600 .000 \\
\hline
\end{tabular}

Sumber: UD. Vanela. November, 2013

\section{Proses Split Off Pia UD.Vanela}




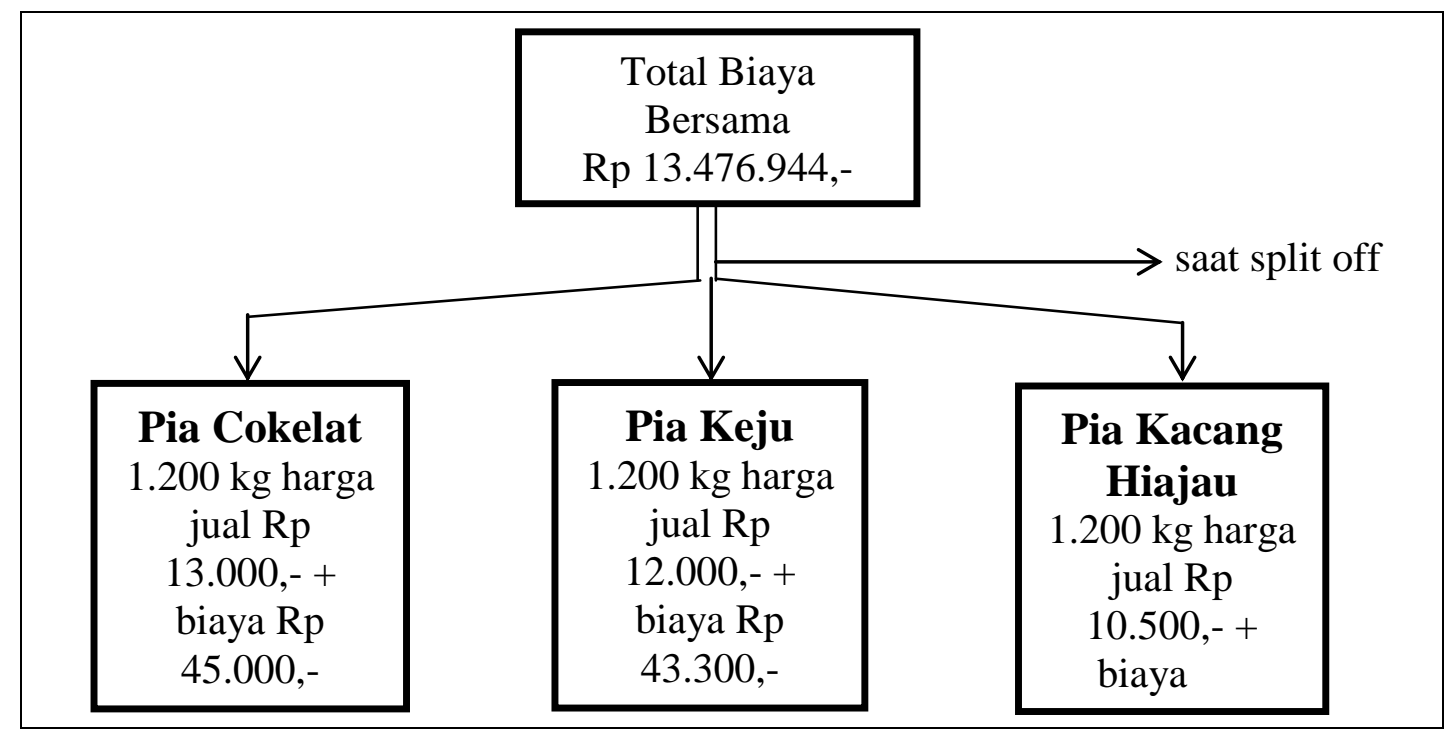

Gambar 2 : Proses split off Pia UD. Vanela. November, 2013

\section{Perhitungan Setelah Split Off}

Tabel 3: Data Harga Jual Hipotesis UD. Vanela November 2013

\begin{tabular}{|c|c|c|c|c|}
\hline Produk & Unit & Harga Jual & $\begin{array}{c}\text { Biaya } \\
\text { Tambahan }\end{array}$ & $\begin{array}{c}\text { Harga Jual } \\
\text { Hipotesis }\end{array}$ \\
\hline Pia Cokelat & 1.200 & x Rp 13.000 & - $\quad \operatorname{Rp} 45.000$ & $=\operatorname{Rp} 15.555 .000$ \\
\hline Pia Keju & 1.200 & x Rp 12.000 & $\operatorname{Rp} 43.300$ & $=\operatorname{Rp} 14.356 .700$ \\
\hline Pia Kacang Hijau & 1.200 & x Rp 10.500 & Rp 30.000 & $=\operatorname{Rp} 12.570 .000$ \\
\hline \multicolumn{4}{|l|}{ Total } & $=\operatorname{Rp} 42.481 .700$ \\
\hline
\end{tabular}

Sumber : Diolah sendiri. November, 2013

Alokasi biaya bersama adalah sebagai berikut :

1. Pia Cokelat $=\underline{R p 15.555 .000} \times \mathrm{Rp} 13.476 .944$

$\operatorname{Rp} 42.481 .700$

$=\operatorname{Rp} 4.934 .686 / \mathrm{pak}$

2. Pia Keju $=\frac{\operatorname{Rp~} 14.356 .700}{\operatorname{Rp} 42.481 .700} \times \operatorname{Rp} 13.476 .944$

$=\mathrm{Rp} 4.554 .536 / \mathrm{pak}$

3. Pia Kacang Hijau $=\operatorname{Rp} 12.570 .000 \times$ Rp 13.476.944

$\operatorname{Rp} 42.481 .700$

$=\operatorname{Rp} 3.987 .721 / \mathrm{pak}$

Dari data diatas biaya/harga pokok per pak adalah :

1. Untuk Produk Pia Cokelat $=\frac{(\operatorname{Rp} 4.934 .686+\mathrm{Rp} 45.000)}{1.200}$ 
2. Untuk Pia Keju $\quad=\quad \frac{(\mathrm{Rp} 4.554 .536+\mathrm{Rp} 43.300)}{1.200}$

$$
=\quad \operatorname{Rp} 4,149
$$

$$
=\quad \operatorname{Rp} 3,831
$$

3. Untuk Pia Kacang Hijau $=\frac{(\operatorname{Rp} 3.987 .721+30.000)}{1.200}$

$$
=\quad \operatorname{Rp} 3,348
$$




\section{Perhitungan Harga Pokok Produk Alokasi Biaya Bersama dan Menurut UD. Vanela Tabel 4: Perbandingan Harga Pokok Produk}

\begin{tabular}{|c|c|c|}
\hline Nama Produk & $\begin{array}{c}\text { Alokasi Biaya } \\
\text { Bersama }\end{array}$ & UD. Vanela \\
\hline $\begin{array}{ll}\text { - } & \text { Pia Cokelat } \\
\text { - } & \text { Pia Keju } \\
\text { - } & \text { Pia Kacang Hijau }\end{array}$ & $\begin{array}{l}* \operatorname{Rp} 4,149,- \\
\operatorname{Rp} 3,831,- \\
\operatorname{Rp} 3,348,-\end{array}$ & **Rp 13.476.944,- \\
\hline
\end{tabular}

Sumber: Diolah sendiri. November 2013

Keterangan :

* Penjelasan biaya dapat dilihat pada perhitungan harga pokok per pak

** Penjelasan biaya dapat dilihat pada perhitungan harga pokok produk UD. Vanela

Berdasarkan tabel perbandingan diatas dapat dilihat bahwa perbedaan pengalokasian biaya sangat berbeda karena UD. Vanela memperhitungkan harga pokok produk untuk keseluruhan produk sehingga biaya-biaya yang seharusnya dialokasikan per produk tidak dialokasikan sesuai semestinya, sedangkan untuk perhitungan alokasi biaya dapat dilihat bahwa pengalokasian biaya jelas karena telah diperhitungkan sesuai dengan pengalokasian biaya yang semestinya yang menggunakan metode harga pasar atau nilai harga jual relative.

\section{Kesimpulan}

\section{PENUTUP}

Berdasarkan hasil penelitian yang telah dilakukan mengenai pengalokasian biaya bersama pada UD. Vanela, maka dapat disimpulkan sebagai berikut:

1. Perusahaan telah melakukan perhitungan harga pokok produk dengan cara perusahaan sendiri, namun biaya-biaya tersebut tidak dialokasikan sesuai dengan seharusnya sesuai dengan yang diajarkan dalam buku sumber yang ada.

2. Dengan menggunakan metode nilai harga jual relative. pengalokasian biaya-biaya menjadi lebih jelas sesuai dengan pengalokasian biaya-biaya yang seharusnya.

\section{Saran}

Dari pembahasan dan kesimpulan diatas, maka penulis ingin memberikan beberapa sumbangan pemikiran atau saran bagi UD. Vanela yang menjadi objek penelitian, antara lain:

1. Sebaiknya UD. Vanela mulai melakukan pengalokasian biaya bersama guna mengetahui penelusuran biaya dengan lebih jelas dengan menggunakan metode nilai harga jual, karena metode ini dianggap tepat dan mudah untuk digunakan serta proses perhitungannya sederhana dan mudah untuk dimengerti.

2. Perusahaan harus lebih teliti dalam mengalokasikan biaya-biaya yang terjadi dalam menghasilkan dan memasarkan produk sehingga perhitungan harga pokok produk dapat dilakukan secara akurat. Harga pokok produksi juga menentukan nilai persediaan untuk tujuan pelaporan keuangan internal dan eksternal. 


\section{DAFTAR PUSTAKA}

Bustami, Bastian,dkk, 2009. Akuntansi Biaya: Teori dan Aplikasi. Jakarta: Graha Ilmu.

Carter, William K, 2009. Akuntansi Biaya. Edisi Keempat Belas. Terjemahan. Jakarta: Salemba Empat. Halim, Abdul. 2007. Dasar-Dasar Akuntansi Biaya. Edisi Keempat. Yogyakarta: BPFE.

Hardiarta. 2006. Penerapan Pengalokasian Biaya Bersama Untuk Produk Utama dan Perlakuan Akuntansi Terhadap Produk Sampingan pada PG Rejo Agung Baru Madiun. Skripsi tidak diterbitkan. Surabaya: Unair.

Horngren, Charles T. 2009. Cost Accounting:A Managerial Emphasis. Thirteenth Edition. New Jersey: Prentince Hall.

Hansen, Mowen, 2006. Cost Management. 4th Edition. Singapore: South Western.

Mulyadi. 2009. Akuntansi Biaya. Edisi Lima. Yogyakarta: UUP AMP YKPN.

Mursyidi. 2008. Akuntansi Biaya. Bandung: Refika Aditamana.

Romadhonisp, 2010. Analisis Alokasi Biaya Bersama dalam Rangka Penentuan Laba pada PD. Krupuk Adi Makmur. (http://romadhonisp.wordpress.com) Diakses September, 06, 2013.

Sunarmi, 2012. Analisis Alokasi Biaya Bersama Untuk Produk Bersama Sate Kambing dan Tongseng pada UD. Pak Bardan. (http://sunarnie.blogspot.com). September, 04, 2013.

Sugiyono. 2008. Metode Penelitian Kuantitatif dan $R \&$ D. Bandung: Alfabeta.

Sugiono. 2012. Metode Penelitian Kualitatif Kuantitatif dan $R \& D$. Bandung.

Riduwan. 2010. Skala Pengukuran Variabel-Varibel Penelitian. Bandung: Alfabeta.

Warindrani K. Armila, 2006. Akuntansi Manajemen. Edisi Pertama. Yogyakarta.

Witjaksono, Armanto, 2006. Akuntani Biaya. Yogyakarta: Graha Ilmu. 